\title{
ENGLISH LISTENING BLENDED LEARNING: THE IMPLEMENTATION OF BLENDED LEARNING IN TEACHING LISTENING TO UNIVERSITY STUDENTS
}

\author{
Mahendra Puji Permana Aji \\ Nusantara PGRI University \\ inbox@mahendrapuji.web.id
}

\begin{abstract}
As one of the English skills, listening needs more than one instance in hearing because it is not only hearing but also understanding and interpreting the meaning of the conversation. Therefore, to make the students interested and easy to understand in listening, the lecturer applied blended learning. The primary focus of this research is to observe the implementation of blended learning in teaching listening. This is a qualitative research of which the subject is the students in one class. There are 28 students, 9 males and 19 females. The data were collected by interviewing the listening lecturer, observing the activities in the classroom and giving the questionnaire to the students. The result of the research showed that the implementation of blended learning in teaching listening at university was able to improve the students' listening skill. In summary, this study demonstrated that the use of blended learning in teaching listening offered ways for lecturers to be more effective in the teaching and learning process and brought positive outcomes for the students.
\end{abstract}

Keywords: Blended learning, listening, teaching

\begin{abstract}
Abstrak
Sebagai salah satu keterampilan dalam bahasa Inggris, keterampilan menyimak memerlukan lebih dari satu keterampilan karena menyimak bukan hanya merupakan keterampilan mendengarkan tapi juga memahami dan menginterpretasikan maksud percakapan. Oleh sebab itu, untuk membuat siswa tertarik dan lebih mugah memahami dalam menyimak, guru menggunakan metode pembelajaran campuran. Fokus utama penelitian ini adalah mengamati implementasi pembelajaran dengan menggunakan metode campuran dalam mengajar keterampilan menyimak. Penelitian kualitatif ini menggunkan siswa dalam satu kelas sebagai subjek penelitian; ada 28 siswa yang terdiri dari 9 siswa laki-laki dan 19 siswa perempuan. Pengumpulan data dilakukan dengan mewawancarai guru keterampilan menyimak, mengamati kegiatan dalam kelas dan menyebarkan kuesioner pada siswa. Hasil penelitian ini menunjukkan bahwa implementasi metode campuran pada pembelajaran keterampilan menyimak di tingkat universitas mampu meningkatkan kemampuan menyimak siswa. Sebagai ringkasan, penelitian ini menunjukkan bahwa penggunaan metode ini menungkinkan guru untuk lebih efektif dalam proses belajar mengajar dan membawa dampak yang positif bagi siswa.
\end{abstract}

Kata Kunci: pembelajaran campuran, menyimak, pengajaran 


\section{Introduction}

Listening is a skill of language so that it can be developed through practices. Teachers can help students enhance their listening skills using media such as videotape, audiotape or computer with activities to complete either at home or in the language laboratory with particular materials. Students can practice listening to vocabulary, sentence structures and dialogues in the target language. According to Lindsay \& Knight (2006, p. 48):

Learners need to develop the following skills: (1) learning to listen in various ways, (2) adapting the way they listen according to the text and the reason for listening, (3) recognizing the features of spoken English, (4) using visual and textual clues to help them, (5) listening activity-asking for repetition, clarification, etc. and (6) developing their background knowledge.

Moreover, students listen in different ways depending on what they are listening to and why. Students use some strategies to control a conversation by asking a person to speak more slower, explain what they have said, and repeat something. If not, they will lose the opportunity to learn and communicate successfully.

Furthermore, at university level listening is a major skill that every English student must have in the target language. Listening skills in language learning have not received sufficient attention although forty percent of daily communication is spent on listening. Moreover, "listening remains one of the least understood processes in language learning" (Kavaliauskiene, 2011, p. 1).

In the classroom, the listening learning process may not run smoothly. The students still feel that listening is difficult because the materials are difficult too; the speaker's pronunciation is found difficult to understand because they just listen to it once or twice from the audio. Getting stuck for listening in English sometimes occurs to any language learners. This can be caused by learners' shortage of practice listening in English.

The students' difficulties occur when they practice listening in English. This can be caused by the restraint in the classroom, and although lecturers are well aware of the need to provide their students with opportunities to practice listening in different and varied contexts, this is sometimes just not feasible given time-tabling constraints. For example, the students have 100 minutes once week in every class. They come to the class, listen to the audio once or twice, and then work through the task based on their listening. This approach is called the traditional learning in the classroom.

The simple definition of traditional learning is face-to-face learning. This method is used by the teaching staff in the lecture rooms. In this study the students meet with the instructor at the same time in one place and mainly rely on the teacher for lecturing and discussing the topics with them. This on-going classroom based process can become monotonous, as students come to the class listening to the recording, then doing the task on the paper as given by the lecturer. In traditional learning the students can not be active in listening activity. Because the students are given materials by the lecturer, there is no preparation from the students before they learn the material.

Considering the factors above, the lecturer changes the way of teaching. She tries to blend between traditional learning and e-learning or it is called blended learning. Blended learning is the solution for language learning in listening class for students. In blended learning situations, one needs to consider how students learn through both face-to-face and online discussions. Mark Belles (2014) defines that 
blended learning combines face-to-face interaction with a teacher in a brick-and-mortar school location, with additional instruction-whether live and or recorded-conducted in an online learning environment that allows for digital content, personalized learning, and collaboration with fellow students.

Based on the statement above, blended learning is the application of high-technology in online listening that can be combined with traditional learning in listening subject. This learning can be called the best learning in listening skill because blended learning processes do not only occur in the classroom or face to face but also outside the classroom using media. It's an effective teaching method in teaching listening.

\subsection{The Concept Of Listening Skill}

There are several definitions of listening explained by scholars. Lindsay and Knight (2006, p. 47) mention that listening is a receptive skill, i.e. we receive language rather than produce it. According to Brown (2006, p. 1) "listening is so challenging, teachers need to think carefully about making our activities successful and our content interesting”. Based on the statements above, listening is important in the interpreting and understanding process learning a foreign language. It is the way of gathering the information from other people. To help the process them, Lindsay and Knight (2006, p. 48) suggest that learners need to develop the following skills: 1) learning to listen in various ways, 2) adapting the way they listen according to the text and the reason for listening, 3) recognizing the features of spoken English, 4) using visual and textual clues to help them, 5) listening actively - asking for repetition, clarification, etc., 6) developing their background knowledge.

\subsection{The Concept Of Blended Learning}

Blended learning has been defined as a mixture of traditional learning and online learning (Williams, 2002; Osguthrope \& Graham, 2003). It is also defined as the integration of e-learning tools such as virtual learning environment with face-to-face learning (Welker $\&$ Berardino, 2006). The aim of this type of learning is to join the advantages of face to face classroom learning with the advantages of e-learning to enhance the learning environment (Bleed, 2001).

In the current study the blended learning refers to a combination of online and face-to-face methods in response to the learners' needs and for the achievement of instructional objectives. This means that multiple approaches, methods and resources to teaching or to educational processes are combined and utilized by the teacher who now expects the students to learn not only from the assigned web pages and communication tools (e.g. email, discussion board and chat rooms) but also from face to face lectures, tutorials, person to person discussions and seminars. Examples include combining technology-based materials and traditional print materials, group and individual study, structured pace study and self-paced study, conference calls, tutorial and coaching. It may also include CD-ROM courses, video, simulations and integrated learning systems. Overall,the best mix of resources is used to provide an optimum learning experience for all the students. So, it can be said that blended learning is a combination of face to face learning and technology learning which is a good learning. When teachers are in face to face session with their students, they sometimes play the traditional role of teacher in front of class, but more often they are creating small and individualized instructional plans to meet the needs, gaps and interests of their students. 


\subsection{The Process Of Blended Learning}

Steps of blended learning offer guidance for lecturer and students in the process of designing and implementing blended learning in university courses. Bath and Bourke (2010, p. 6) have explored these steps of blended learning, all in an effort to learn more about how to improve the lecturer's and students' learning and success in listening.

The following is the steps of blendeding learning Bath and Bourke $(2014$, p. 6):

a. $\quad$ Plan the integrated blended learning into your course followed by:

1) What is the situation?
a) Developing new course
b) Redesigning course

2) What is the course context?
a) Course level considerations
b) Program, Faculty, Group influences

3) Who are the students?

a) Year of study (1st year students or later year students)

b) Class numbers (is it a large class or a small class)

c) Student type (international or national students, students from a low/high socio-economic background, age students, students with work/ family commitments)

b. Design and develop the blended learning elements:

1) Content and resources

a) Lecturer materials

b) Lecturer recordings

c) Virtual classroom

2) Digitized reading or documents

a) Learning support resources

b) Assessment

c) Communication

c. Implementing the blended learning design:

1) Implementing blended learning course

a) Getting the students ready for blended learning

b) A good ending

d. Review (evaluate) the effectiveness of blended learning design)

1) Peer evaluation
a) "Classroom" performance
b) Learning materials

2) Student learning
a) Student's self-reported knowledge
b) Student work

3) Student experiences
a) Informal feedback
b) Student Evaluation of Teaching
c) Customized course survey

Based on the description of the theories that have been explained, blended learning is important to build students' interest in learning, moreover with the development of information technology in education that has given rise to a new environment called blended learning, in this case the role of teachers to foster their students' interest is needed. Blended learning is a 
combination of online class and traditional class, with the use of various technologies. The benefits of blended learning are to improve the learning effectiveness, that students will gain more experience and knowledge, and it also has the potential to balance out and optimize the learning program development and the deployment of cost and time.

\section{Methods}

\subsection{Research Design}

There are many research designs used by Educational researchers. One of them is qualitative research. According to David Nunan (1992, p. 231), "Qualitative data is a data which are recorded in non-numerical form". In qualitative research, the data is not presented in numeral and it does not need statistics formula. The data is presented in description. The purpose of descriptive qualitative is to make description of situation or certain procedures or technique. The subject of research is one class. There are 28 students, 9 boys and 19 girls.

\subsection{Research Procedure}

The procedure of this research was divided into 3 steps, such as preparation, processing of data collection, and finishing.

a. Preparation of the research

In the preparation activities the writer started to formulate the title of research. Then the researcher conducted the research preparation, such as setting a research design, determining the framework of the research, and developing interview questions. When all the research preparation had been completed, the writer proceeded to obtain the permission letter from the University.

b. Data collection

Many activities during the data collection process were as follows:

1) Interviewing the lecturers

The first things that done by the writer to get the data was interview. The interviewees were the lecturers and students which divided into two phases: preand post- class and laboratory activities.

2) Sending Questionnaires

The next activity was giving questionnaires to the lectures and the students after class session.

3) Conducting Observation

During the class observation, the researcher observed and made notes about everything that happen in the class (pre-, during learning process and post- class activities).

c. Finishing

At the finishing stage, the writer analysed the data and wrote the research findings.

1) Analyzing the data

2) Writing the research result

In this activity the researcher revealed the research finding and conclusion.

\section{Findings and Discussion}

\subsection{The Process of Blended Learning in Teaching Listening}

The following are process of blended learning:

a. Planning

Based on the observation, the researcher found that the lecturers set their in planning the lecturer set of course aims and teaching and learning activities. Its also supported the laboratory classroom, recording, speakers, computer, and virtual class. And resources 
to support the virtual class are free WIFI at the campus and web sites for student's access (Edmodo).

b. Designing and developing

The lecturer used handbook for guiding the teaching and learning process in the classroom. Besides handbook the lecturer also used syllabus, set of teaching material, and book chapters. Furthermore, the lecturer assessed students at virtual class. The lecturer maintained her control of the class through activeness in participation, direct and non-confrontational interaction (the students' participated actively when they took the material from Edmodo virtual class). By virtual class the lecturer can monitor the students' progress frequently and effortlessly. For example, by using online assignment submission students' work was automatically date and time stamped. Virtual classroom or Edmodo can also be used for group discussion between student-student, and studentlecturer.

c. Implementing

Implementing is the main activity in the process of blended learning; the lecturer prepared the class that the students would ready for blended learning. In this case the lecturer provided ongoing guidance for any students' activity. The lecturer involved in the online activities such as tutors (for example, discussed and demonstrated how the content might be used in real life, gave brief feedback during an activity) and the lecturer monitored students' participation.

\section{d. Reviewing}

The lecturer always reviewed the students' performance and learning material in the end of the class. The lecturer reviewed the students' performance at the classroom, in this case the lecturer gave feedback to the students about their problem during the teaching-learning process. Learning material must also be reviewed by the lecturer, that the lecturer could provide the appropriate material for the students.

\subsection{The Reason Used Blended Learning}

The underlying reason for using blended learning in teaching listening is in terms of an imbalance of students' listening skill. The lecturer can be faced with students who come from different level of listening skill. In this case the lecturer wants to improve the students' listening skill, particularly students who were lack of concentration during their listening session. The students were then recomended to not only learn in their class but also outside the class, as they only had once or twice in a week; it is not sufficient to get students' concentration in listening.

In addition, the lecturer also hoped that the use of blended learning can increase and motivate students who have good listening skill to be more active in their listening class. However, the implementation of blended learning was hindered by the internet access, because not all of the students had a good internet access to download the material from Edmodo. Thus, to solve the problem, the lecturer used group work, that the students could work together.

\subsection{The Student's Response Toward The Implementation of Blended Learning in Listening Class.}

The students' response was derived from the questionnaire, observation and interview. The questionnaires were completed by 28 students aiming to explore the students rensponses about the use of blended learning in the listening subject by the lecturer. The writer found that 
from the 12 items in the questionnaire, more students mention 2 options, 'strongly agree' and 'agree', out of 5. It means that the students give positive response about the implementation of blended learning in listening course. Firstly, the students believe that they learn English best by a listening activity so that they are able to pay attention to the lecturer. It means that the students enjoy the listening activity. Secondly, most of the students agree with this learning method and they believe that it can improve their listening skill as they have much time to study at home. Therefore, they are ready to learn listening in the classroom. Thirdly, the students think that listening activity should be conducted more than once. Online learning may be used to improve their listening skill other than face to face learning in the classroom. Fourthly, most of the students agree that blended learning is a good teaching method applied in listening class.

The result also shows that the students' response in the implementation of blended learning is good enough. The lecturer said that the students become more active in the listening class after the lecturer uses this type of blended learning method. This good response is also shown in their speaking skill, pronunciation, and intonation when speaking in English. In the blended learning method, students are able to listen wherever and whenever they are and do.

The result of the questionnaire suggests that almost of the students feel better in listening class throught the use of blended learning method in their classroom. Blended learning may motivate the students to be active in the listening lesson and understand the material.

\section{Discussion}

Based on the data analysis, the implementation of blended learning in teaching listening was effective. In preparation, the lecturer has prepared the virtual classroom in "edmodo" used to upload the materials where the students are able to access and to learn the material. Next, in the blended learning process, the lecturer has become a facilitator for who monitored their students' activities and played her role as their lecturer.

In teaching listening, she had applied each step of blended learning such as planning, designing, implementing and reviewing. Planning is the first step of blended learning process; the lecturer has to understand the students' classrooms' situation. In the preparation, the lecturer prepared the lecturers' material, lecturers' recording, and virtual classroom. In the implementation, the lecturer guided the students in each of the activities. In the review, the lecturer has two evaluations for the students (students' performance and learning material). All of them were used to improve the students' performance in listening skill.

In other words, blended learning is an effective teaching method to develop the students' listening skill. The lecturer can solve the students' problems in a group discussion which enable peer-learning among the students.

\section{Conclusion}

This study investigated the implementation of blended learning in teaching listening. The results showed significant differences in the students' behavior being engaged in the listening activity. Following the lecturer's use of "blended", the listening activities were inside and beyond the classroom. It means that the students have sustained their listening practices in their daily activities.

In addition, the results indicated that blended learning has not only influenced the students' listening skills but also their speaking skill. The findings of this study imply some suggestions to language lecturers in using different teaching approach in teaching listening, particularly blended learning approach. In summary, this study demonstrated that the use of 
blended learning in teaching listening offered ways for more effective teaching and learning process and brought positive outcomes to the students.

\section{References}

Bath D., \& Bourke J. (2010). Getting Started With Blended Learning. Griffth University Press

Bersin, J. (2004). The Blended Learning Book Best Practices, Proven Methodologies, and Lessons Learned. USA. Library of Congress Cataloging

Bleed, R. (2001). A hybrid campus for a new millennium. Educause Review, 36(1), pp. 16-24.

Brown, S. (2006). Teaching Listening. Cambridge: Cambridge University Press

Kavaliauskiene, G. (2011). Blended Learning In ESP Listening. English for Specific Purposes Worldjournal, 31 (10), 201. Mykolas Romeris University, Vilnius, Lithuania

Lindsay, C. \& Knight, P. (2006). Learning And Teaching English A Course For Teachers. New York: Oxford University Press.

Miller, S. (2012). Qualitative Data Analysis. New York:Sage Publication, (Online), available at: http://www.sagepub.com, downloaded January $30^{\text {th }} 2015$.

Nunan, D. (1992). Research Methods in Language Learning. New York: Cambridge University Press.

Osguthorpe, R. \& Graham, C. (2003). Blended learning environments: Definitions and directions. The Quarterly Review of Distance Education, 4 (3), pp.227-233.

Richards, J.C. \& Renandya, W.A. (2002). Methodology in Language Teaching An Anthology of Current Practice. USA: Press Syndicate of The University Of Cambridge.

Sharan, M.B. (2002). Qualitative Research in Practice. San Francisco:Jossey-Bass A Wiley Compony. (Online), available at: www. josseybass .com, downloaded January $30^{\text {th }} 2015$.

Thomas, J.R., Nelson, J.K. \& Silverman, S.J.(Ed). (2011). Research Methods in Physical Activity, Sixth Edition. (Online), available at: http: // www. humankinetics .com, downloaded January $30^{\text {th }} 2015$.

Watson, J. (2008). Blending Learning: The Convergence of Online and Face-to Face Education. Evergreen Consulting Associates. USA. Nacol (North American Council for Online Learning). (Online), available at: web www. nacol .org, downloaded November $28^{\text {th }} 2014$.

Welker, J. \& Berardino, I. (2006). Blended learning: understanding the middle ground between traditional classroom and fully online instruction. The Journal of Educational Technology Systems, 34 (1), pp.33-55.

Williams, C. (2002). Learning on-line: A review of recent literature in a rapidly expanding field. Journal of Further and Higher Education, 26(3), pp.263-272. 